PACS: $92.70 .-\mathrm{j}$, 42.79.Ek.

\title{
MAXIMUM TEMPERATURE IN AN IDEAL GREENHOUSE
}

\author{
O. Ivashtenko \\ V. N. Karazin Kharkiv National University, Kharkiv, Ukraine \\ Svobody Sq. 4, Kharkiv, Ukraine, 61022 \\ E-mail: arinaivashtenko@gmail.com \\ Received April 28, 2017
}

The greenhouse is a tool for the accumulation of solar energy and its conversion into heat. The article investigates the heating of the greenhouse caused by the difference in the transmissivity of glass in different wavelength ranges. Firstly, some facts from the history of the phenomenon investigation are presented. The principle of greenhouse operation is considered. Then we explain the greenhouse effect theoretically using a simplified model, and carry out an experiment. In our experiment, the heating of a $1 \mathrm{~m}^{2}$ surface greenhouse model has been observed. The temperature changes have been registered, and the ultimate temperature has been measured. Further, a model of an ideal greenhouse is proposed in order to reduce heat losses. The main principles and generalizations of the greenhouse effect are discussed. The role of the glass transmission spectrum, which is one of the most important factors determining the maximum temperature is investigated. Maximum temperatures for different spectra are compared. We calculate theoretically the maximum temperature, which can be achieved in an ideal greenhouse under ideal conditions. Then we consider other factors limiting temperature growth. Finally, the ways of application of the greenhouse effect in the development of solar collectors are indicated.

KEYWORDS: greenhouse effect, heating by radiation, idealized model, maximum temperature, solar collector

\section{МАКСИМАЛЬНА ТЕМПЕРАТУРА В ІДЕАЛЬНОМУ ПАРНИКУ \\ О. Іваштенко \\ Харківський начіональний університет ім. В. Н. Каразіна, Харків, Украйна} пл. Свободи 4, м. Харків, Украӥна, 61022

Парник - це пристрій для акумуляції сонячної енергії і її перетворення в тепло. У статті досліджується нагрівання парника, обумовлене різницею проникної здатності скла в різних діапазонах довжин хвиль. Представлені факти з історії вивчення явища. Розглянуто принцип роботи парника. За допомогою спрощеної моделі парниковий ефект досліджено теоретично, а також представлені результати експерименту. Експериментально простежено нагрівання моделі парника площею $1 \mathrm{~m}^{2}$. Зареєстровано зміну температури 3 часом і отримано значення граничної температури. Далі запропоновано модель ідеального парника для зменшення тепловтрат. Обговорюються головні принципи та узагальнення парникового ефекту. Досліджується роль спектра пропускання скла, який є одним з найважливіших факторів, що визначають максимальну температуру. Порівнюються граничні температури для кількох спектрів. Теоретично розраховано максимальну температуру, якої можна досягти в ідеальному парнику за ідеальних умов. Розглянуто фактори, що обмежують зростання температури. Вказано шляхи застосування парникового ефекту при розробці сонячних колекторів.

КЛЮЧОВІ СЛОВА: парниковий ефект, нагрівання випромінюванням, ідеалізована модель, максимальна температура, сонячний колектор

\section{МАКСИМАЛЬНАЯ ТЕМПЕРАТУРА В ИДЕАЛЬНОМ ПАРНИКЕ}

\section{А. Иваштенко}

Харьковский начиональный университет имени В. Н. Каразина, Харьков, Украина пл. Свободы 4, г. Харьков, Украина, 61022

Парник - это устройство для аккумуляции солнечной энергии и её превращения в тепло. В статье исследуется нагревание парника, обусловленное различием пропускающей способности стекла в разных диапазонах длин волн. Представлены факты из истории исследования явления. Рассмотрен принцип работы парника. С помощью упрощённой модели парниковый эффект исследован теоретически, а также представлены результаты эксперимента. Экспериментально исследовано нагревание модели парника площадью $1 \mathrm{~m}^{2}$. Зарегистрировано изменение температуры со временем и получено значение предельной температуры. Далее предложена модель идеального парника для уменьшения теплопотерь. Обсуждаются главные принципы и обобщения парникового эффекта. Исследуется роль спектра пропускания стекла, который является одним из самых важных факторов, определяющих максимальную температуру. Сравниваются предельные температуры при различных спектрах. Теоретически рассчитана максимальная температура, которой можно достичь в идеальном парнике при идеальных условиях. Рассмотрены факторы, ограничивающие рост температуры. Указаны пути применения парникового эффекта при разработке солнечных коллекторов.

КЛЮЧЕВЫЕ СЛОВА: парниковый эффект, нагревание излучением, идеализированная модель, максимальная температура, солнечный коллектор

Greenhouses are used to promote the growth of plants and to increase temperature using only solar energy. The same principle is extensively used to heat air and water. It also has prominent implications in the field of climate.

The study and explanation of the greenhouse effect phenomenon began in the $18^{\text {th }}$ century. Natural philosophers tried to understand the increase of the Earth's temperature and established the analogy between the heat-conserving 
capacity of the greenhouse and that of the atmosphere. Joseph Fourier (1786-1830) studied the distinction between the light heat (chaleur lumineuse) received on the Earth from the sun and the dark heat (chaleur obscure) reflected back into the atmosphere. He also pointed at the lesser facility with which dark heat passes through the atmosphere, thus bringing about higher temperatures than would otherwise have been the case. In describing this phenomenon, Fourier drew on experiments conducted by Horace-Benedict de Saussure (1740-1799). De Saussure had constructed an instrument he called a "solar captor" that consisted of a box with an interior covered with black cork, into which equidistant layers of glass were inserted. He used his instrument in experiments around Mont Blanc to show that the temperature under the glass was much higher than outside, and that it remained the same irrespective of the altitude [1] [3].

The incident solar radiation passes through the glass. The surface absorbs visible light and re-emits it in the longwave infrared. Glass is a bad transmitter of the longwave infrared radiation, which is why it can not pass back easily. It stays inside the greenhouse, causing the temperature to rise (Fig. 1(left)). Indeed, in the schematic we see that the solar radiation spectrum is almost entirely in the glass' transmission range, so most of this radiation penetrates freely into the greenhouse. But the thermal radiation from the surface lies predominantly outside of the range of transmission, so the radiation can not go out (Fig. 1(right)). The transmittance coefficient of glass $k$ depends on the wavelength $\lambda$ and is determined as the ratio of the transmitted radiation to the incoming radiation.

Robert Williams Wood (1868-1955) doubted that this effect played the key role in the elevation of temperature. From his point of view, it appeared much more probable that the part played by the glass was the prevention of the escape of the warm air heated by the ground within the enclosure [2]. We agree that the prevention of air convection plays a key role in greenhouse heating at low temperatures. However, in this article we will focus on the study of the temperature increase caused by the difference in glass transmittance. We will show that this effect is also important, especially at high temperatures.

In general, the purpose of this work is to study the impact of the mentioned effect on heating of the greenhouse. We try to find the maximal possible in principle temperature and to understand what is the reason for stopping of its growth. Indeed, it is possible to eliminate the air convection and to reduce considerably the heat transfer by thermal conductivity. So, other ways of heat losses become decisive. Imaging consequent optimizations, we will predict the maximum temperature for different levels of idealization reaching finally the limit caused by the Second Law of Thermodynamics. This work is rather an overview of concerned general principle that has many interesting and very complicated details.
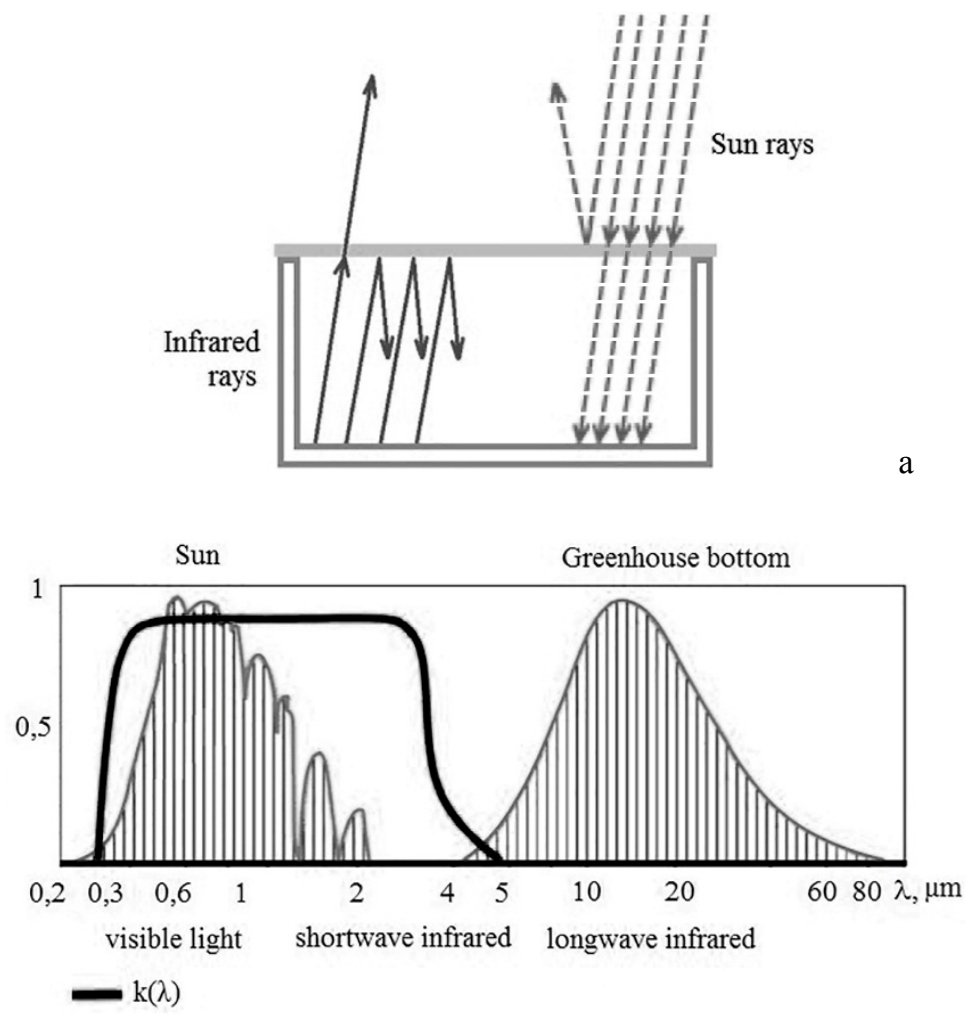

$\mathrm{b}$

Fig.1. A schematic that shows how a greenhouse operates (a). Sunlight (dashed arrows) penetrates into the greenhouse, then the bottom absorbs it and reemits it in the form of infrared light (solid arrows). As the glass is opaque to this radiation, it cannot leave the greenhouse. The emission spectrum of the Sun and of the greenhouse (b). The transmittance spectrum of window glass $k(\lambda)$ is shown with a black line [4]. We see that the ordinary window glass is mostly transparent to the Sun's rays, but opaque to the greenhouse bottom's low-temperature radiation. This is what causes the greenhouse effect. 


\section{METHODS}

Despite the fact that the glass delays radiation and prevents the escape of the heated air, there are heat losses caused by emission of the heated surface and heat conductivity of the glass and the walls. Considering these losses, we can write the heat balance equation for the greenhouse as follows:

$$
P_{\odot}=P_{e m}+P_{\text {cond }}
$$

where $P_{\odot}$ is the energy coming from the Sun, $P_{e m}$ is the energy emitted by the greenhouse's absorbing layer, and $P_{c o n d}$ is the energy loss due to heat conduction. Consider separately each component of this equation.

To find the radiation power received by the greenhouse' absorbing layer, we should take into consideration the spectral intensity of solar radiation on the ground level (Fig. 2) and calculate the total power received by the greenhouse according to the value of the glass transmission coefficient $k(\lambda)$. Our model treats the window as a selective mirror, so that it reflects the untransmitted radiation. Thereby we obtain the following equation

$$
P_{\odot}=\int(1-A) \cdot I_{\odot}(\lambda) \cdot k(\lambda) d \lambda
$$

where $A$ is albedo of the surface, $I_{\odot}$ is the solar radiation intensity at the Earth's surface, and $k$ is the transmittance of the glass.

Now let us consider the heated greenhouse absorbing layer's radiation. A part of it passes through the walls, the floor and the glass, and so leaves the greenhouse. To reduce losses, it is necessary to cover the walls and the floor with a foil. Some types of foil are capable of reflecting $99 \%$ of infrared radiation, so that the walls and the floor become insulated. The emitted power transmitted through the glass is

$$
P_{e m}=\int I_{e}(\lambda) \cdot k(\lambda) d \lambda
$$

Here, $k$ is the transmittance of the glass and $I_{e}$ is the intensity of radiation, $I_{e}(\lambda)=f \cdot\left(1-A_{\lambda}\right)$, where $f$ is the black body spectral emissivity. According to the Planck's law,

$$
f(\lambda, T)=\frac{2 \pi h c^{2}}{\lambda^{5}\left(e^{\frac{h c}{k T \lambda}}-1\right)} .
$$

Losses caused by thermal conductivity (glass, walls, floor) are estimated in the following equation

$$
P_{\text {cond }}=-æ \frac{S \Delta T}{l},
$$

where $æ$ is the thermal conductivity coefficient, $S$ is the surface area, $\Delta T$ is the temperature difference, and $l$ is the material's depth.

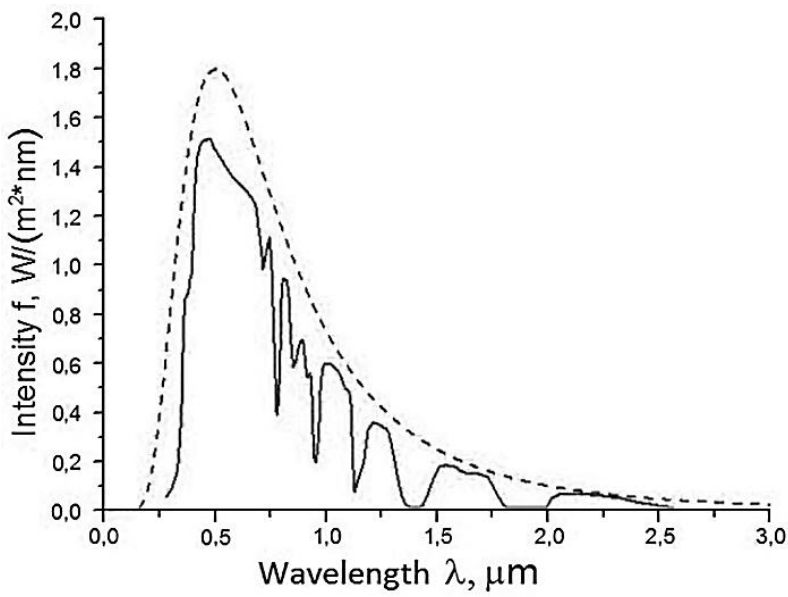

Fig. 2. A schematic showing the intensity of solar radiation at the Earth's surface [6] (solid line).

The blackbody radiation spectrum $(\mathrm{T}=5700 \mathrm{~K})$ is shown with a dashed line. Here we note that the impact of the atmosphere on this intensity is very significant, especially at small wavelengths. 


\section{EXPERIMENT}

Let us observe the functioning of the greenhouse. We construct the experimental model taking into account the above-mentioned equations and carrying out optimizations according to them (Fig. 3). We also pay respect to our limited capabilities. During our experiment, the air temperature in the shade was approximately $5{ }^{\circ} \mathrm{C}$, and the sky was cloudless. The greenhouse bottom was oriented perpendicularly to the sun rays.
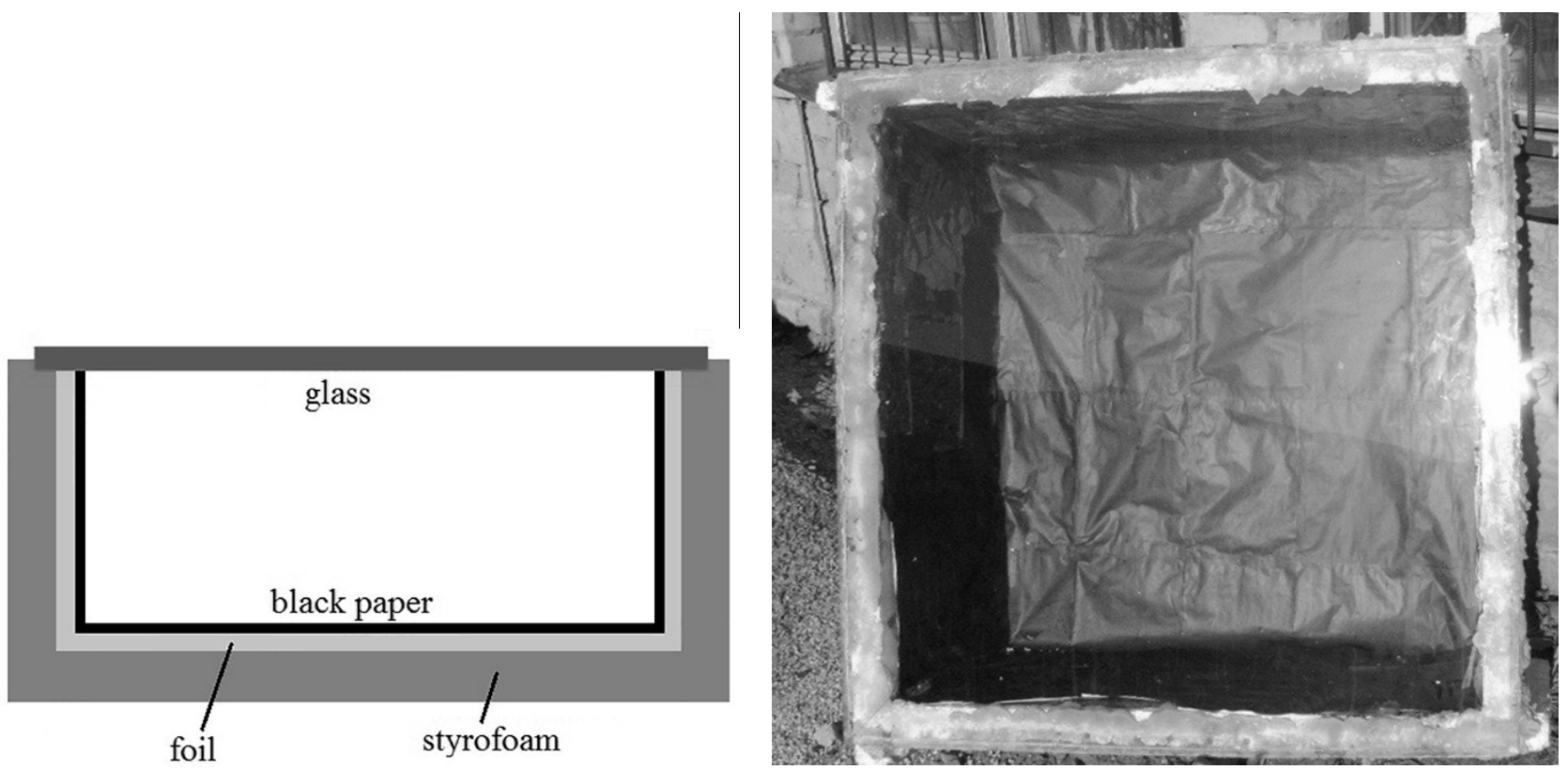

Fig. 3. Our experimental model (left). It is a rectangular box coated with styrofoam.

The interior walls of the box are covered with aluminum foil and black paper. In our experiment, we use conventional window glass. Our greenhouse (right) constructed according to the schematic. The area of the bottom is just about $1 \mathrm{~m}^{2}$. The wall thickness is $5 \mathrm{~cm}$, the glass thickness is $4 \mathrm{~mm}$.

\section{RESULTS}

During the operation of our experimental model, the majority of heat losses were caused by the styrofoam's and glass' heat conduction. The temperature in the greenhouse becomes constant due to the balance between the energy coming in from the Sun and the energy transferred to the environment. Gradually saturating (Fig. 4), the temperature in our experiment rose above 100 degrees. The maximum temperature we achieved was $111^{\circ} \mathrm{C}$.

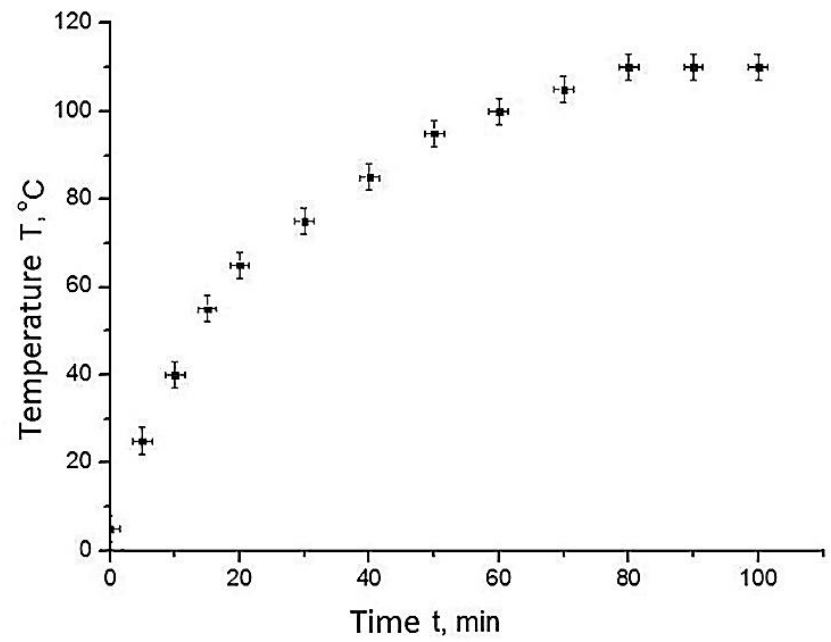

Fig. 4. Plot of greenhouse temperature versus time. The temperature increases and finally reaches saturation. The maximum temperature achieved in the experiment was $111^{\circ} \mathrm{C}$.

Let us verify the suitability of the proposed balance equations for description of the experiment. The bandwidth of the used glass in the visible range is about $87 \%$, the surface albedo is about 0.05 . The intensity of solar radiation at the Earth's surface is approximately $1.000 \mathrm{~W} / \mathrm{m}^{2}$, but is subjected to large temporal and spatial variations, depending on the weather conditions, the latitude, the altitude, the atmospheric pollution etc. We experimentally found temperature differences: $3{ }^{\circ} \mathrm{C}$ near the glass, $95^{\circ} \mathrm{C}$ near the bottom, and $65^{\circ} \mathrm{C}$ near the sidewalls. We also know that the thermal conductivity of styrofoam is $0.04 \mathrm{~W} /(\mathrm{m} \cdot \mathrm{K})$, that the thermal conductivity of the glass is $0.7 \mathrm{~W} /(\mathrm{m} \cdot \mathrm{K})$, the thickness of 
the styrofoam layer is $5 \mathrm{~cm}$, and that the thickness of the glass is $4 \mathrm{~mm}$. We plug the available data into the calculation formulas and get the following result. $P_{\odot} \approx 830 \mathrm{~J} / \mathrm{s}, P_{e m}+P_{\text {cond }} \approx 5 \mathrm{~J} / \mathrm{s}+705 \mathrm{~J} / \mathrm{s}=710 \mathrm{~J} / \mathrm{s}$ (Eq. 1). The discrepancy is about fifteen percent. However, this result confirms the applicability of such simplified theory.

\section{DISCUSSION \\ Theoretical generalizations}

In most ordinary garden greenhouses, the temperature increases mainly due to the glass or polyethylene film preventing air convection. Our experimental model also provides styrofoam insulation, which reduces losses caused by the thermal conductivity. However, the heating that results from this is relatively small. After the verification of the proposed principle, we use it to predict the outcome in other conditions. Our task is to reach the maximum temperature. Let us upgrade the model to minimize heat losses.

Separating the absorbing layer of the greenhouse from the shell, it is possible to eliminate direct heat transfer to the walls and to the bottom. To avoid the transmission of heat through the air inside the greenhouse, let us evacuate it. Now, the thermal conductivity losses are negligible. Only losses caused by the greenhouse's radiation-absorbing layer remain, and we cannot completely eliminate them because of the glass' transmission properties. We imagine these optimizations and present a model of an ideal greenhouse (Fig. 5).

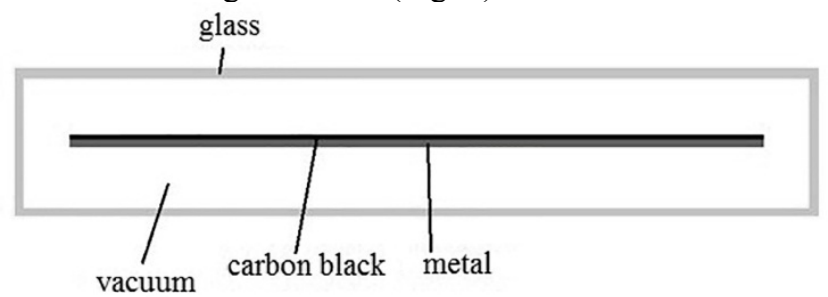

Fig. 5. A model of an ideal greenhouse.

It is a plate coated with carbon black, isolated from the environment, in which light penetrates through the glass. In this case, we are maximizing the temperature of the plate itself.

Of course, ideally, the greenhouse could be placed in orbit, where the intensity of solar radiation is not influenced by the atmosphere, and where heat losses via air convection and heat conductivity vanish. However, let us confine ourselves to Earthly conditions. Now we rewrite the initial equation of heat balance for the ideal greenhouse.

$$
\int(1-A) \cdot I_{\odot}(\lambda) \cdot k(\lambda) d \lambda=\int I_{e}(\lambda) \cdot k(\lambda) d \lambda
$$

After reaching certain conditions, the temperature in this greenhouse will also become constant. The reason for the establishment of the balance is Wien's displacement. Initially the greenhouse's absorbing layer emits in the infrared range, in which the glass does not transmit. However, as the temperature rises, the emission spectrum shifts toward shorter wavelengths, where the glass becomes transparent. Then it reaches the state when the greenhouse emits as much energy as it consumes. That is, it sets the balance between the absorbed and the emitted energy per unit time, and the temperature reaches its maximum, ceasing to rise.

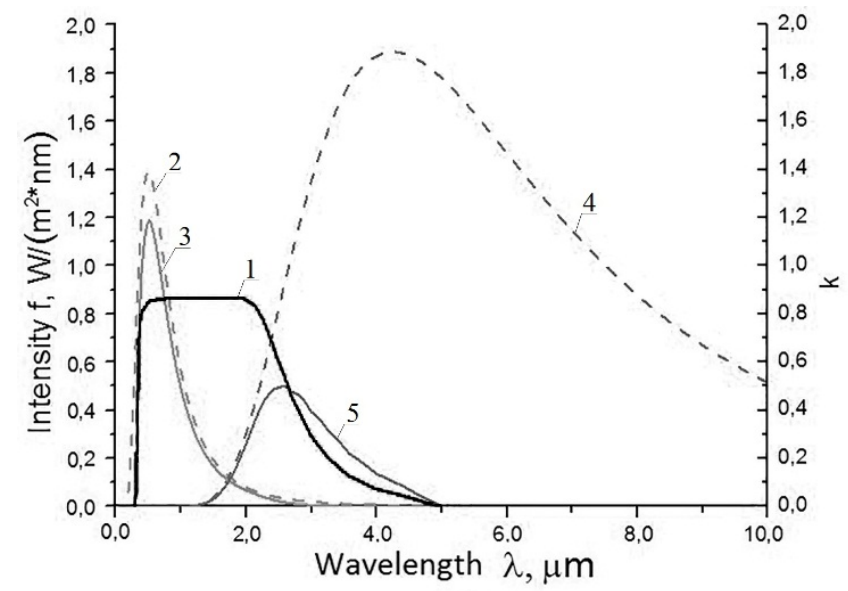

Fig. 6. Transmittance coefficient $k(\lambda)(1)$; incoming solar energy (2), absorbed solar energy (3); energy emitted by the heated surface (4), energy that passes through the glass and leaves the greenhouse (5). The incoming solar energy spectrum is simplified and corresponds to the blackbody radiation spectrum at the temperature at $5700 \mathrm{~K}$ (we also take into consideration the distance from the Sun). The radiation of the greenhouse's bottom corresponds to a blackbody heated up to $680 \mathrm{~K}$. In this case the area under the line (3) equals the area under the line (5), that means the heat balance. 
What is the temperature, at which the heat balance will be achieved? Let us describe the spectrum of the greenhouse bottom's radiation that penetrates through the glass (Fig. 6). It is not difficult to verify that the integral of this function equals $830 \mathrm{~W} / \mathrm{m}^{2}$ when the temperature of the plate is approximately $680 \mathrm{~K}$. So, with the conditions in our experiment, the temperature that we could ideally achieve is $680 \mathrm{~K}$.

It should be noted that in the current model, the key role in the greenhouse's operation is played by the glass. Its transmittance area determines the temperature that can be reached by an ideal greenhouse. For example, if the transmission coefficient is the same for all wavelengths $(k(\lambda)=$ const $)$, the greenhouse can only be heated to $370 \mathrm{~K}$ (Fig. 7). Our task is to find a glass transmission spectrum that would allow the greenhouse to reach the maximum possible temperature.

Let us consider a new model: one that includes glass that transmits in a very narrow range, localized at some wavelength (Fig. 8).

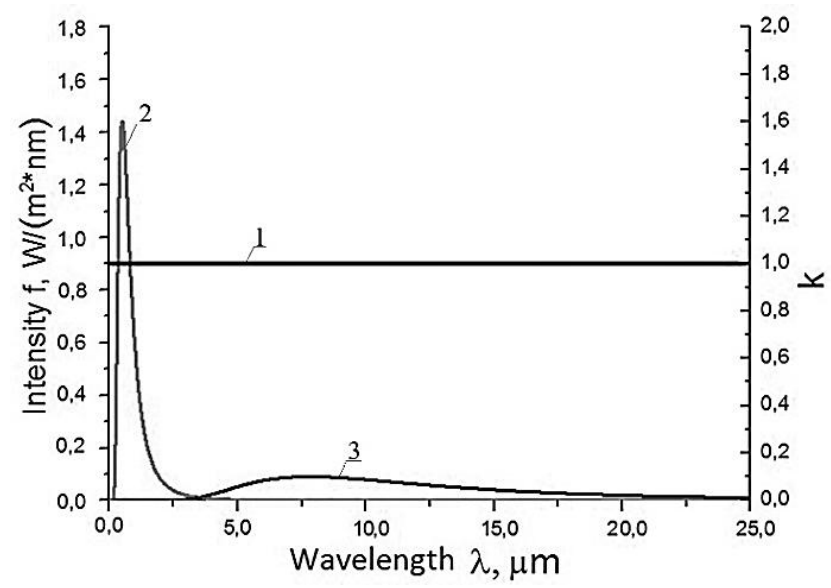

Fig. 7. (left) The transmittance of the glass $k(\lambda)(1)$, sun (2) and greenhouse (3) radiation spectra.

When $k(\lambda)=$ const, the greenhouse can only be heated up to about $370 \mathrm{~K}$ only. This picture shows that if there is no difference in the glass transmittance for visible and infrared radiation, we get lower temperature. That is, the prevention of the escape of the heated air is not the only important function of the glass.

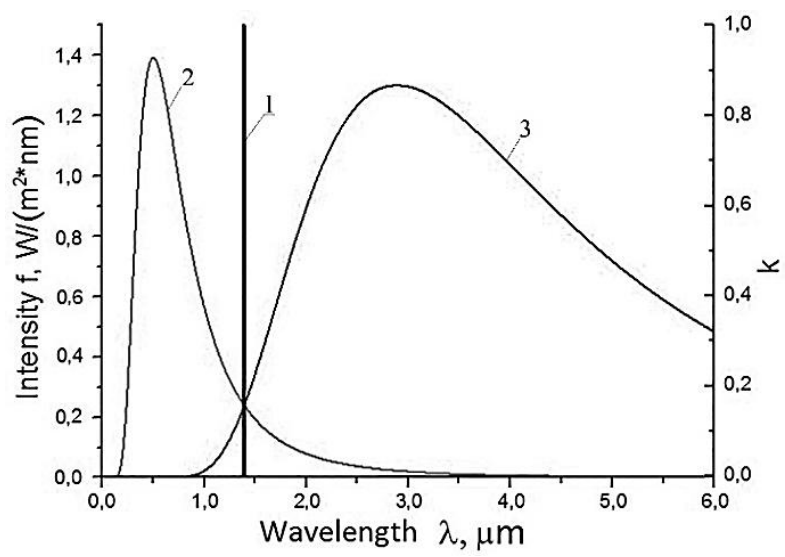

Fig. 8. (right) Transmission $k(\lambda)$ localized at a specific wavelength (1), sun (2) and greenhouse bottom (3) radiation spectra. The intersection point of the two spectrum curves reaches this wavelength where the transmission of the ideal glass is localized. This is the equilibrium between the absorbed energy and the emitted energy.

In this case, the temperature in the greenhouse will increase until the intersection of the Sun's radiation spectrum curve (taking into account the distance to the Earth) and the greenhouse's radiation spectrum curve reaches this wavelength (in other words, until the two objects emit the same amount of energy at this wavelength). Then the balance will be achieved, and the heating will stop. When the intersection point shifts to shorter wavelengths, we get a higher final temperature. To simplify the calculations, we will not take into account the impact of the Earth atmosphere. If the Sun and the greenhouse emit according to Planck's law, we obtain the following equation:

$$
\frac{2 \pi h c^{2}}{\lambda^{5}\left(e^{\frac{h c}{\lambda k T}}-1\right)}=\frac{r^{2}}{R^{2}} \frac{2 \pi h c^{2}}{\lambda^{5}\left(e^{\frac{h c}{\lambda k T_{0}}}-1\right)},
$$

where $r$ is radius of the Sun, $R$ is the distance from the Sun, $T_{0}$ is temperature of the Sun, and $T$ is temperature of the 
plate in the greenhouse. From this, we get:

$$
T=\frac{h c}{\lambda k \ln \left(\frac{R^{2}}{r^{2}}\left(e^{\frac{h c}{\lambda k T_{0}}}-1\right)+1\right)} .
$$

This dependence of the temperature in the greenhouse on the wavelength at which the transmission of the glass is localized is shown on the graph (Fig. 9). For sufficiently small $\lambda$ we get $\rightarrow T_{0}$, and for sufficiently big $\lambda$ we get $T \rightarrow T_{0} \frac{r^{2}}{R^{2}}$. So, in the ideal greenhouse model, isolated from all heat losses besides radiation, with a delta-function glass transmission localized at a wavelength of about one nanometer, neglecting the influence of the atmosphere, it is theoretically possible to reach solar temperatures. Higher temperatures cannot be achieved because of the Second Law of Thermodynamics.

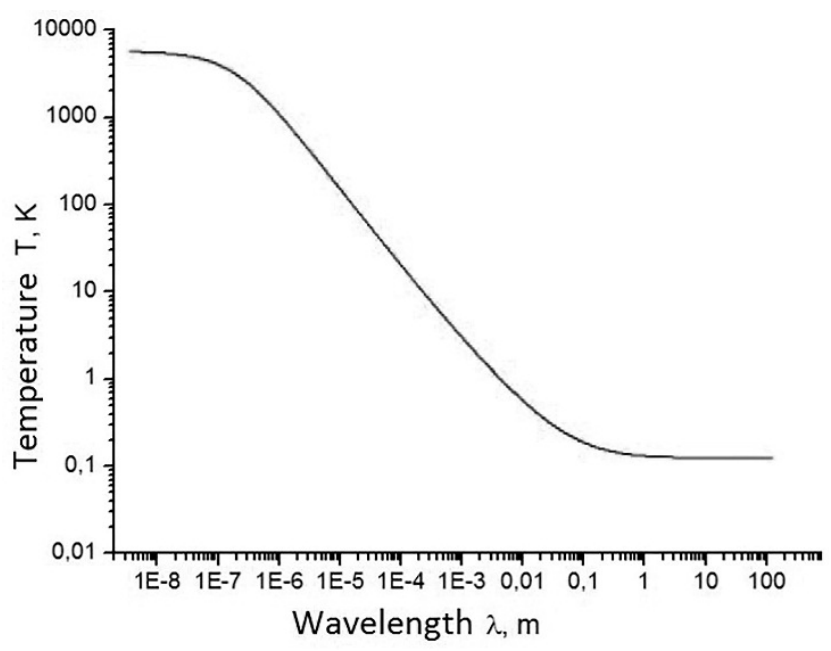

Fig. 9. Dependence of the greenhouse temperature on the wavelength at which the glass transmission spectrum is localized (logarithmic scale). For sufficiently small wavelengths, the temperature in the ideal greenhouse tends to reach solar values.

In real life, the impact of the atmosphere and other factors is so significant that we cannot neglect them. The Sun's radiation spectrum is too different from the blackbody, especially in the short wave range that is considered in the case of maximum temperature. That is why in reality it is impossible to obtain temperatures close to solar values. For the same reasons, it is also impossible to find this maximum temperature analytically. We can only try to estimate its possible value, assuming that at least the plate in the greenhouse radiates as a blackbody (Fig. 10).

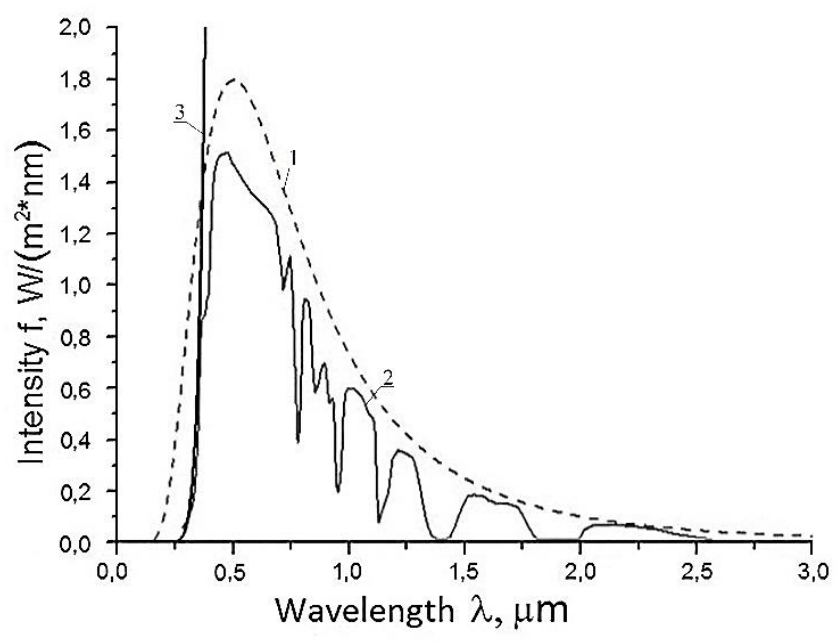

Fig. 10. Plank's curve for the Sun (1), the actual solar radiation spectrum (2) and the tangent curve (3) of the blackbody radiation $\operatorname{spectrum}(T \approx 2200 \mathrm{~K})$.

As the Sun's atmosphere-modified radiation spectrum differs from a blackbody, the considered intersection point cannot reach an arbitrarily small wavelength. That is why in this case the temperature can only approach about $2000 \mathrm{~K}$ - quite below the solar value.

\section{Dead-ends}

As has been mentioned above, the influence of the heat conduction of the greenhouse walls and air convection is practically very significant. The consideration of these factors greatly complicates the model and makes it much more 
interesting and comprehensive. Unfortunately, this is beyond the scope of the posed problem. We also can not get the transmittance spectrum of the glass from first principles at the molecular level. There are many kinds of glass, each with their own transmission spectrum, (see [4]), but there is no way to get glass with arbitrary desired properties. It also should be mentioned that our reasoning is done under the assumption that the window reflects the untransmitted radiation. What happens if the window absorbs it instead? Its properties may change, which is a possibility we haven't considered. From equations (2) and (3) we see that the contribution of the surface albedo is the same as the contribution of the coefficient $k$. In our model, we treated the albedo as a constant. However, in reality, albedo depends on the wavelength and affects the result in the same way as the coefficient $k$, whose influence is investigated in the paper. Therefore, considerations in this case are similar. We can also consider an idealized model for albedo, but it is useless because it is too far from reality. It serves only to understand the dependence of the temperature on various parameters and to find the generalized abstract principles. Thus, many ways to control the temperature in the greenhouse are not covered by our solution of the problem. This paper is only a qualitative, idealized overview of the greenhouse effect principle.

\section{Application}

How can this result be applied? There are devices (called solar collectors) operating on the same principle that are used to accumulate solar energy. Unlike solar cells that produce electricity directly, a solar collector heats a heattransferring material. There are some widespread types of collectors that are used for heating air and water: flat and vacuum solar collectors. When there is no heat intake (the stagnation case), the flat plate collectors can heat water up to 190-210 ${ }^{\circ} \mathrm{C}$. In vacuum solar collectors the heat transfer medium can be heated up to $250-300{ }^{\circ} \mathrm{C}$. Reflectors, different heat transfer agents, and Sun tracking devices are used to increase the efficiency of these installations. House heating and hot water supply can be carried out with the help of collectors. Collectors are easy to use, environmentally friendly and present a promising alternative energy source [5].

\section{CONCLUSIONS}

In our investigation, we have studied the principle of the greenhouse effect based on the dependence of glass transmissibility on wavelength. Having done estimations of heat balance in the greenhouse, we conducted an experiment, traced the change of temperature with time and obtained a maximum temperature of $111^{\circ} \mathrm{C}$. Then we proposed an ideal model that eliminates heat losses by heat conductivity and found the maximum temperature in two idealized cases. In the case of ordinary window glass and an ideal solar radiation spectrum, the maximum temperature is about $680 \mathrm{~K}$. For the real solar radiation spectrum and ideal glass, whose transmittance spectrum is localized at some wavelength, the result is about $2200 \mathrm{~K}$. We also noted that in solar collectors, which are used to convert solar energy into heat, it is possible to obtain a stagnation temperature of $300^{\circ} \mathrm{C}$, which is not too far from our idealized estimation.

\section{Acknowledgements}

The work was done in preparation for the Ukrainian Physicists' Tournament for University Students. I express my sincere gratitude for the help provided by our team supervisor Oleksiy Golubov. I am also very grateful to Bohdan Bidenko, Daria Raspopova, Mykyta Kizilov, Maria Sklyarova as well as to our entire team.

\section{REFERENCES}

1. Crawford E. Arrhenius' 1896 Model of the Greenhouse Effect in Context // Ambio. - 1997. - Vol. 26. - No. 1. - P.6-11.

2. Wood R.W. Note on the theory of the greenhouse // Philosophical Magazine Series 6. - 1909. - P.319-320.

3. Fourier J. Mémoire sur les températures du globe terrestre et des espaces planétaires // Mémoires de l'Académie royale des sciences de l'Institut de France. - 1827. - Vol. VII. - P.585-587.

4. Borulko V., Borulko P, Dubinin A., Marichev A., Popovich S. Glasses absorbing the infrared part of the spectrum (heat absorbing glasses) // The journal Windows. Doors. Stained-glass windows. - 2006. - No.5.

5. Zubkova E. Expensive collector for free energy // Energyland.info. [Online] Available: http://www.energyland.info/analiticshow-90573.htm. - 2012.

6. Iqbal M. Introduction to solar radiation. - Academic Press, 1983. - 136p. 